\begin{tabular}{l|c|c}
\hline ISSN: 0001-5113 & ACTA ADRIAT., & SHORT COMMUNICATION \\
AADRAY & $62(1): 93-97,2021$ & \\
\hline
\end{tabular}

\title{
First record of Eualus drachi Noël, 1978 (Decapoda: Caridea) in the Adriatic Sea
}

\author{
Marin KIRINČIĆ ${ }^{1}$ and Pero UGARKOVIĆ ${ }^{2}$ \\ ${ }^{1}$ Natural History Museum Rijeka, Lorenzov prolaz 1, HR-51000 Rijeka, Croatia \\ *Corresponding author, e-mail: marin@prirodoslovni.com
}

Three specimens of decapod shrimp Eualus drachi Noël, 1978, were found in the red coral remnant collected for commercial purposes near the island Sveti Andrija, Croatia. It is the first record of this species in the Adriatic Sea. The decapod biodiversity of deeper coralligenous habitats, such as the red coral colonies, is poorly investigated in contrast to coastal areas and soft bottoms of traditional trawling grounds. This paper highlights the usefulness of examining the remnants of a commercial coral extraction originating from previously less investigated marine habitats in order to improve the knowledge on the biodiversity of such habitats.

Key words: Decapoda; first record; Caridea; Adriatic Sea; Eualus drachi

\section{INTRODUCTION}

Decapod family of Thoridae is represented exclusively by genus Eualus in Adriatic Sea where this genus was represented by only three known species so far, namely Eualus cranchii, E. occultus and E. sollaudi (ŠTEVČIĆ, 1990), while total of four species of this genus are present in the Mediterranean Sea (D'UDEKEM D'ACOZ, 1999). As a part of the Mediterranean Sea, Adriatic Sea also hosts a large portion of its fauna. Although the Adriatic is one of the most extensively studied seas for decapod fauna (PESTA, 1918; ŠTEVČIĆ, 1990), during the last three decades, many species of decapods have been recorded for the first time (ŠTEVČIĆ, 2002; KIRINČIĆ \& ŠTEVČIĆ 2008). The northern part of the Adriatic Sea, in contrast to its south, has been more extensively investigated (UNGARO et al., 2005). Previous researches were mostly based on the material collected by trawlers and with grabs from the soft bottoms of the circalittoral and lower infralittoral. A significant increase in the number of recorded species of decapods in the recent decades correlates with the increased number of scientists applying SCUBA diving, which enabled samples from previously unexplored microhabitats in the infralittoral and circalittoral zone (GEROVASILEIOU et al., 2016), including the deep vertical walls with colonies of red coral Corallium rubrum. Despite the fact that Corallium rubrum is listed at the IUCN Red List as an endangered species and protected by EU Habitats Directive, the commercial red coral harvesting according to Marine Fisheries Act and bylaw regulations is still allowed in Croatia. The aim of the present work is to report the first record of Eualus drachi Noël, 1978, from the Adriatic Sea, collected in this habitat. 


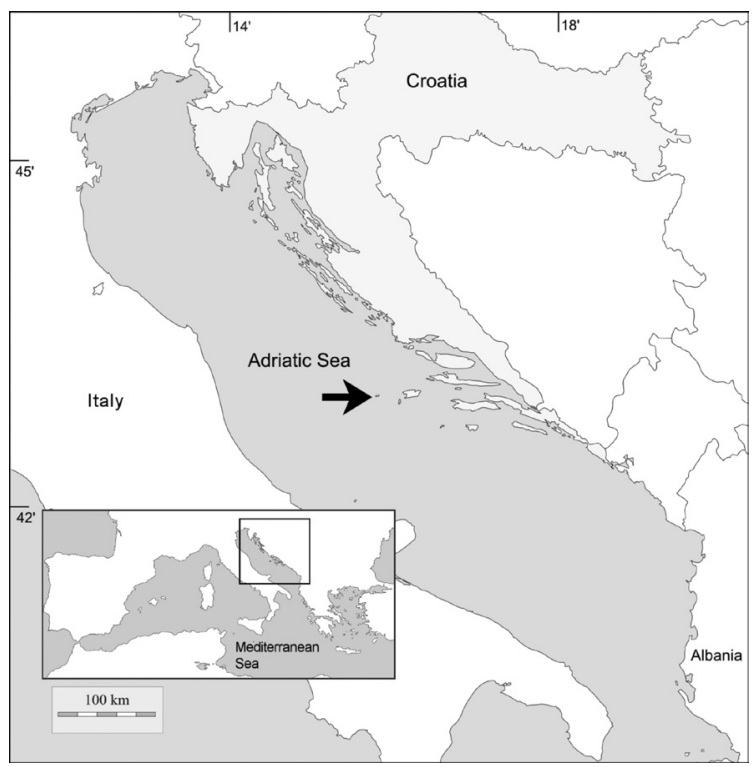

Fig. 1. Geographical map with the collection locality

\section{MATERIAL AND METHODS}

Three specimens of Eualus drachi Noël, 1978, were collected on the NW side of island Sveti Andrija, Croatia (Coordinates: $43^{\circ} 01,420^{\prime}$ $\mathrm{N} 015^{\circ} 43.470$ ' E) (Fig. 1), during a commercial harvesting of red coral Corallium rubrum in the period from $4^{\text {th }}$ to $6^{\text {th }}$ September 2020. Red corals were commercially harvested by a licensed professional using SCUBA diving equipment, at a depth of about 85 meters. The collected harvest was placed underwater in a landing net with a mesh size of $4 \mathrm{~mm}$. During the inspection, the specimens of $E$. drachi were found in two consecutive harvest days in the landing net remnant. All specimens were immediately upon capture placed in 96\% alcohol and are currently preserved and deposited in the Natural History Museum Rijeka, Croatia, catalogued under C1685 and C1686. A key characteristics were examined using the stereomicroscope Olympus SZX10. The specimens were identified following the key of D'UDEKEM D'ACOZ \& WIRTZ (2002). Measurements were taken with interactively selected points in Olympus cellSens Entry 2.2. software using camera Olympus SC180 and Olympus U-TV0.5XC-3 camera adapter.

\section{RESULTS AND DISCUSSION}

All three examined specimens matched an original morphological and ecological description of Eualus drachi Noël, 1978 (NOËL, 1978). Two out of three examined specimens were ovigerous females and one specimen was an adult male. The found ovigerous state for this species correlates with the already recorded ovigerous period for the other adriatic Eualus species (FALCIAI \& MINERVINI, 1992). Total lengths of the specimens (from the peak of the rostrum to the end of the telson) were as follows: spm1 - ovigerous female, $14.73 \mathrm{~mm}$ (Fig. 2); spm2 - adult male, $12.03 \mathrm{~mm}$; spm3 - ovigerous female, $13.24 \mathrm{~mm}$. These lengths fall in the known range for the species provided by NOËL (1978).

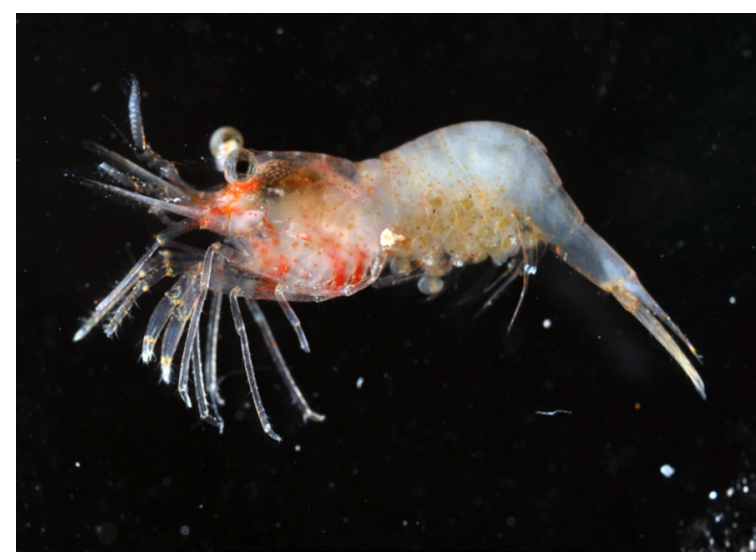

Fig. 2. Examined ovigerous female specimen of Eualus drachi Noël, 1978 (f, T.L. 14,73 mm; C1685)

The specimens of $E$. drachi from this study were examined and compared with already known Adriatic species of genus Eualus (ŠTEVČIĆ, 1990). Identification was also ascertained through comparative analysis using the material of E. occultus and E. cranchi from the Natural History Museum Rijeka collection. The main distinguishing characteristic that separates our specimens from all other Eualus species is the presence of epipod on the third pereiopod, unlike other species where it is present only on the first two pereiopods. The rostrum of our specimens were singletoothed, slender and not short as the one of the E. occultus, which is shorter and usually bifurcated. Adult specimens of E. occultus were longer $(\geq 19 \mathrm{~mm})$ (FALCIAI 


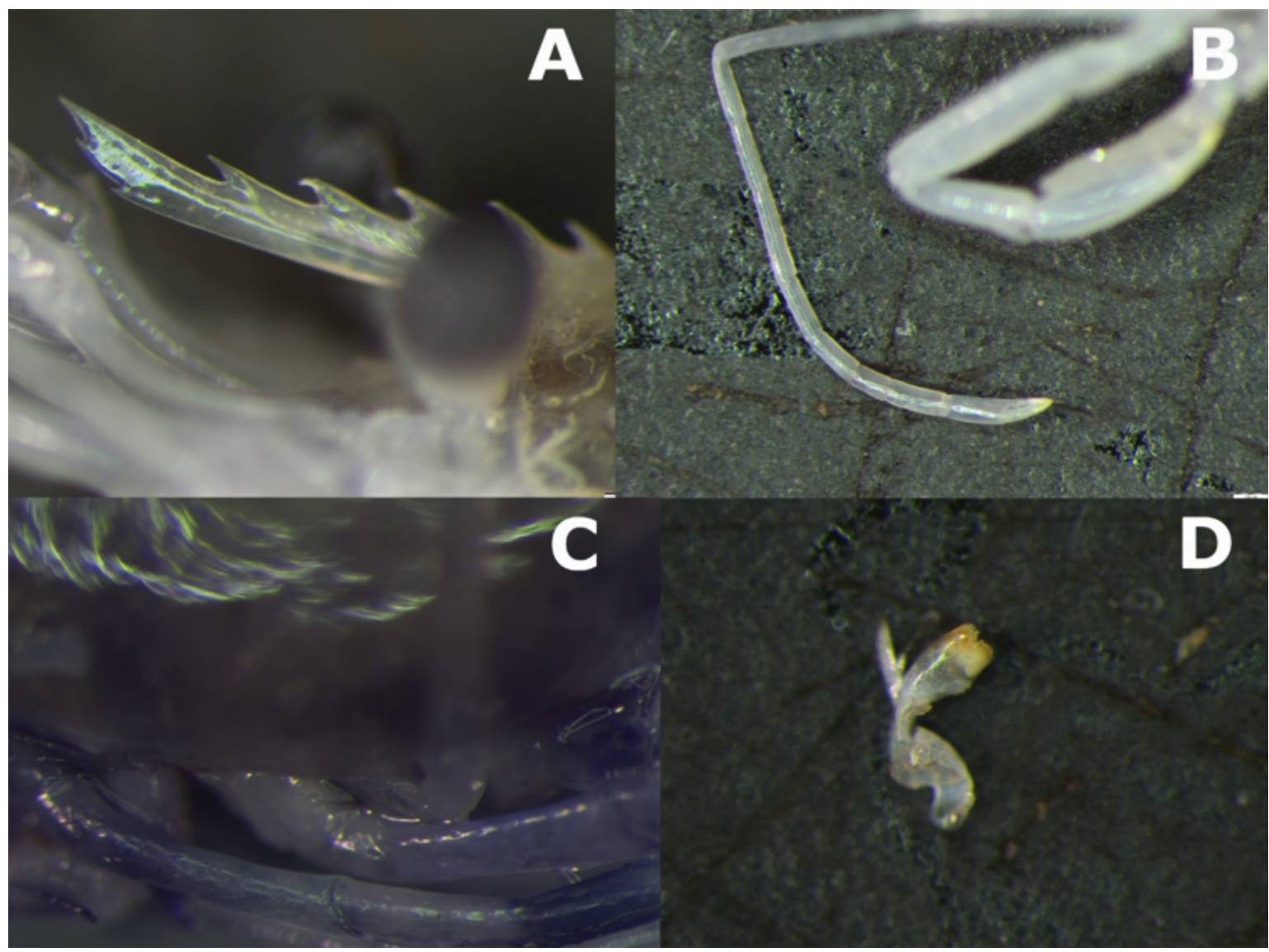

Fig. 3. Distinguishing characters of Eualus drachi Noël, 1978 (f, T.L. 14,73 mm; C1685) ((A)rostrum, (B) carpal segments of $P 2,(C)$ basal part of $P 3$ and (D) mandibula)

\& MINERVINI, 1992) than the known range of $E$. drachi (NOËL, 1978) $(8,8 \mathrm{~mm}-15,4 \mathrm{~mm})$. Both E. occultus and E. cranchi have second carpal segment of second pereiopod slightly longer than broad, unlike E. drachi which has second segment of P2 at least 2,7 times as long as broad. E. cranchi, moreover, has bifurcate or trifurcate short rostrum, only 6 carpal segments on second pereiopods and lacks mandibular palp, unlike long rostrum observed in our specimens with 7 segmented carpus on second periopods and present mandibular palp (Fig. 3). The last character also distinguishes E. sollaudi from our specimens as well as the presence of dark pigment on the non-corneal part of the eyestalk which is absent in our specimens.

The known habitats of E. occultus and E. cranchi are intertidal and coastal waters (D'UDEKEM D'ACOZ \& WIRTZ, 2002). E. drachi prefers profound depths and is usually associated with deep-sea corals and polychaetes (D'UDEKEM D'ACOZ, 1999). The depth at which E. drachi was found $(85 \mathrm{~m})$ extends the known depth range of this species (NOEL, 1987; D'UDEKEM D'ACOZ, 1999; D'UDEKEM D'ACOZ \& WIRTZ, 2002) where the maximum recorded depth was 70 meters. The species has a Mediterranean distribution; from Alboran Sea to Ionian and Aegean Sea (D'UDEKEM D'ACOZ, 1999). Our finding extends the known geographical distribution to the Adriatic Sea where this species has not been recorded earlier. One of the reasons of late finding of this native decapod species in Adriatic Sea can be its cryptic behaviour and body size, like in the case of the first records of shrimp Brachycarpus biunguiculatus (H. Lucas, 1846) for Adriatic (KIRINČIĆ, 2003) and Aegean Sea (KAMPOURIS et al., 2018), species well known from other parts of Mediterranean. They are probably rarely recorded due to their cryptic and 
nocturnal ecological preferences, particularly if SCUBA trained scientists' recreational divers engaged through Citizen Science in the process are not involved (GEROVASILEIOU et al., 2016). These new records also indicate that systematic SCUBA diving expeditions to the deep-sea habitats in the area, particularly coralligenous reefs, could result in more discoveries of other new species in the future.

\section{ACKNOWLEDGMENTS}

We wish to express our sincere gratitude to Mr. Cédric d'Udekem d'Acoz for helpful advices on the identification of the species and for providing us with the required most useful literature for the topic. We would like to thank also the two anonymous reviewers for providing useful comments on an earlier draft of the manuscript.

\section{REFERENCES}

FALCIAI, L. \& R. MINERVINI, 1992. Guida dei crostacei decapodi d'Europa. Padua: Franco Muzzio Editore: $282 \mathrm{pp}$.

GEROVASILEIOU, V., E. PANTERI, T. DAILIANIS $\&$ N. MICHALAKIS. 2016. CIGESMED for divers: Establishing a citizen science initiative for the mapping and monitoring of coralligenous assemblages in the Mediterranean Sea. Biodiversity Data Journal, 4 (4): 23.

KAMPOURIS, T.E., V. KOULOUMPERIS \& I.E. BATJAKAS. 2018. First documented record of palaemonid shrimp Brachycarpus biunguiculatus (Lucas, 1846) from Aegean Sea, Greece. Spixiana 41 (2): 188.

KIRINČIĆ, M. 2003. Brachycarpus biunguiculatus (Lucas, 1846): a new species of shrimp for the Adriatic Sea (Decapoda, Caridea). Crustaceana, 76 (7): 891-894.

KIRINČIĆ, M. \& Z. ŠTEVČIĆ. 2008. Fauna of the Adriatic decapod crustaceans (Crustacea: Decapoda) - status and prospectives. Natura Croatica, 17(2): 131-139.

NOËL, P.Y.1978. New observations on Eualus drachi (Caridea, Hippolytidae) from Mediterranean. Inv.Pesq. 51 (Supl. 1) : 67-72.

PESTA, O. 1918. Die Decapodenfauna der
Adria. Versuch einer Monographie: I-X, 1-500. (Deuticke. Leipzig und Wien).

ŠTEVČIĆ, Z. 1990. Check list of the Adriatic decapod Crustacea. Acta Adriat., 31: 183-274.

ŠTEVČIIĆ, Z. 2002. New observation on the Adriatic decapod fauna (Years 1990-2000). Crustaceana, 75 (3-4): 643-647.

UNGARO, N., G. A. MARANO, L. CERIOLA \& M. MARTINO. 2005. Distribution of demersal crustaceans in the southern Adriatic Sea. Acta Adriat., 46 (1): 27-40.

UDEKEM D'ACOZ, C. D'. 1999. Inventaire et distribution des crustacés décapodes de l'Atlantique nord-oriental, de la Méditerranée et des eaux continentales adjacentes au nord de $25^{0} \mathrm{~N}$ (Inventory and distribution of the Crustacea Decapoda in Northeastern Atlantic Ocean, Mediterranean Sea and adjacent continental waters, north of $25^{\circ} \mathrm{N}$ ). Patrimoines naturels (M.N.H.N./S.P.N.), 40 : 1-383.

UDEKEM D'ACOZ, C. D' \& P. WIRTZ. 2002. Observations on some interesting coastal Crustacea Decapoda from the Azores, with a key to the genus Eualus Thallwitz, 1892 in the Northeastern Atlantic and the Mediterranean. Arquipélago. Life and Marine Science 19A: 67-84.

Received: 1 February 2021

Accepted: 26 March 2021 


\title{
Prvi nalaz vrste Eualus drachi Noël, 1978 (Decapoda: Caridea) u Jadranskom moru
}

\author{
Marin KIRINČIĆ* i Pero UGARKOVIĆ \\ *Kontakt, e-pošta: marin@prirodoslovni.com
}

\section{SAŽETAK}

Tri primjerka kozice Eualus drachi Noël, 1978, pronađena su u ostatku crvenog koralja prikupljenom u komercijalne svrhe u blizini otoka Sveti Andrija, Hrvatska. To je prvi nalaz ove vrste u Jadranskom moru. Biološka raznolikost deseteronožaca dubljih koraligenih staništa (poput kolonija crvenih koralja) slabo je istražena za razliku od obalnih područja i mekog dna tradicionalnih koćarskih područja.

U ovom radu se naglašava korisnost ispitivanja ostataka komercijalne ekstrakcije koralja porijeklom iz prethodno manje istraženih morskih staništa kako bi se poboljšalo znanje o biološkoj raznolikosti takvih staništa.

Ključne riječi: deseteronožci (Decapoda); prvi nalaz; Caridea; Jadransko more; Eualus drachi 
